\title{
Determinants of adoption of agri-environmental practices by maize producers organised in cooperatives in the Centre region of Cameroon
}

\author{
Achille Jean JAZA FOLEFACK ${ }^{1 *}$, Loveline Viviane TCHOUA $^{2}$ and \\ George Achu MULUH ${ }^{3}$
}

\author{
${ }^{I}$ Department of Agricultural Economics, University of Dschang, Cameroon. \\ ${ }^{2}$ Centre Régional d'Enseignement Spécialisé en Agriculture (CRESA) Forêt-Bois, Yaoundé, Cameroun. \\ ${ }^{3}$ Faculty of Economics and Management, University of Dschang, Cameroon. \\ ${ }^{*}$ Corresponding author, E-mail: ajazafol@yahoo.fr; Tel: (+237) 695844205
}

\begin{abstract}
In response to various environmental problems facing the intensive mode of agricultural production, this study analysed the factors influencing the adoption of agri-environmental practices by maize producers organised in co-operatives in the Centre region of Cameroon by using the case study of PIDMA project. For this reason, the survey was undertaken in all the 15 villages grouping maize producers in two out of the four cooperatives under the regional coordinating unit of the project (PIDMA). Data on the socio-economic situation of producers, level of knowledge and applicability of environmental practices were gathered in the study area from 50 out of 88 (i.e. $56.8 \%$ ) active maize producers. The descriptive field results revealed that the adoption of agri-environmental practices was related to social, psychological and economic characteristics of producers. The binary logit model results indicated that the adoption of agri-environmental practices was associated with the frequency of PIDMA agricultural training and cultivated area under maize. However, certain variables such as gender, age, education level, marital status, cost of implementing practice, lack of funding, labour type, time spent for the implementation of the practice, income source, technical and professional support did not seem to be associated with the adoption of agri-environmental practices. In conclusion, the study recommended to the maize farmers, the setting up of working groups of at least 10 maize producers in order to practice rotations in the fields of each member of the group. The study also recommended the agricultural development projects to define and provide relatively simple mechanisms to enhance farmers' performance such as financial assistance, demonstration workshops in the fields and to allocate environmental assistants to each co-operative's headquarters.
\end{abstract}

(C) 2020 International Formulae Group. All rights reserved.

Keywords: Cooperative, logit model, maize producer, agricultural development project, socio-economic factors.

\section{INTRODUCTION}

The Cameroonian economy relies mainly on agriculture which contributes to about 35\% of Gross Domestic Product (GDP), employs two-thirds of the active population and generates more than half of the total export earnings (Jaza, 2017; Minader, 2018). Within the agricultural sector, the contribution of food crops is important to the country's economy. Among the mostly cultivated food crops, maize (Zea mays) ranks third in terms of volume of production after cassava and banana. The high demand of maize for human consumption, animal feed and beer production motivated 
most farmers to give their preference on the cultivation of this crop (Marinis et al., 2019). Since the last decade, maize is mainly cultivated for commercial purposes like coffee or cocoa. As compared to these cash crops and because of its short production cycle, maize provides nowadays significant incomes for producers (Jaza, 2017; Minader, 2018; Bokobana et al., 2019). Hence to favour the maize producers, there is an attempt of intensification of farming methods of cultivation of this crop throughout the country (Minader, 2018).

However, with economic liberalisation, the chances of developing sustainable agriculture in Cameroon seem difficult to achieve. This is because the objectives of diversification and expansion of food crops as well as improving agricultural productivity seem a priori incompatible with those of preservation of natural resources. According to Nonga (2002), this incompatibility mortgages the effectiveness of poverty reduction strategies.

In response to this need to improve domestic production while preserving the environment, the Cameroonian government launched in 2014 the Agricultural Market Investment and Development Project (PIDMA) for a period of five years. Financed by the World Bank, this project (PIDMA) aimed at accompanying agricultural cooperatives in the optimisation of productivity of food crops like maize (PIDMA, 2014a). This, on the one hand, by providing improved maize varieties that are high yielding and on the other hand strategic documents in which agri-environmental practices are prescribed (PIDMA, 2014b).

The PIDMA project counts among its staff a socio-environmental specialist in charge of following up the national environmental regulations. In order to make cooperatives more responsible with respect to the socioenvironmental management plan, it regularly organizes training workshops to educate farmers on integrating socio-environmental aspects in their agricultural activities (PIDMA, 2014a; PIDMA, 2014b).

Most of the agri-environmental practices promoted through individual and group training by the PIDMA project are designed to take care of accidental spill off of pesticides, toxicity, non-compliance to the recommended dosage and repeated use of the same plots for the same crops over time (PIDMA, 2014a). In the case of accidental spill off of pesticides, farmers are encouraged to make use of registered pesticides, crop rotation, and compliance with the recommended dosage by the manufacturer, as well as use of good cropping practices. In the latter case, crop rotation is the recommended agri-environmental practice (Tchoua, 2017). Furthermore, the PIDMA project also promotes agri-environmental practices in relation to insect pests in the locality (Table A1).

The objectives of these agrienvironmental practices as defined in the National Environmental Management Plan Volume II in Cameroon are both to reduce the negative impacts of agriculture on the environment and to promote its amenities in eliminating the use of chemicals not complying with the regulations (PIDMA, 2014a; PIDMA, 2014b; Minef, 2016; Tchoua, 2017). More emphasis has been placed on communicating to farmers, information on environmental problems through technical assistance and extension actions, so as to induce voluntary changes in agricultural practices to improve environmental results (Vojtech, 2010). Unfortunately, the lack of available information on these environmental problems very often lead to additional uncertainties among farmers, which are in addition to the risks incurred in the current production environment (price volatility of maize, regulatory constraints, etc) influencing the adoption of agri-environmental practices established (Binswanger and Sillers, 2003; Pruneau et al., 2006). If the maize producers perceive these practices as riskier, they may not adopt the agri-environmental measures.

A multitude of studies on the behaviour of adoption of agri-environmental practices have been carried out worldwide by several authors, among others Dupraz (2003); Mitchell (2006); Michaud et al. (2009); Vojtech (2010); Mwangi and Kariuki (2015); 
Table A1: Common symptoms and agri-environmental practices used to treat pests and diseases by the selected maize producers in PIDMA project.

\begin{tabular}{|c|c|c|}
\hline Diseases & Symptoms & Agri-environmental practices \\
\hline $\begin{array}{l}\text { Maize cob worm } \\
\text { (Helicoverpa Zea) }\end{array}$ & $\begin{array}{l}\text { Causes concentrated } \\
\text { damage around the tip of } \\
\text { the spike }\end{array}$ & $\begin{array}{l}\text {-Paint application around the base of maize plants } \\
\text { to kill the adults as they come out of the ground. }\end{array}$ \\
\hline $\begin{array}{l}\text { Root rootworm } \\
\text { (Diabrotica } \\
\text { virgifera) }\end{array}$ & $\begin{array}{l}\text { Reverses plants from } \\
\text { their base }\end{array}$ & $\begin{array}{l}\text {-Crop rotation (e.g. maize/soya beans). } \\
\text {-Use synthetic insecticides (teflutrine) during } \\
\text { planting }\end{array}$ \\
\hline $\begin{array}{l}\text { Maize flea beetle } \\
\text { (Chaetocnema } \\
\text { pulicaria) }\end{array}$ & $\begin{array}{l}\text { Causes bacterial blight of } \\
\text { the leaves }\end{array}$ & $\begin{array}{l}\text {-Use a mixture of ash and lime applied in light } \\
\text { powder coating on young plants. These include } \\
\text { the charcoal of the inflorescences on the cob and } \\
\text { the bare charcoal attacks on the spikes and stems } \\
\text { causing black malformations and dusts. } \\
\text {-Avoid mechanical injuries and damage caused } \\
\text { by herbicides. } \\
\text {-Respect the formulas of balanced fertility }\end{array}$ \\
\hline Maize anthracnose & $\begin{array}{l}\text { Burns the leaves and rots } \\
\text { the stem }\end{array}$ & $\begin{array}{l}\text {-Use resistant varieties } \\
\text {-Practice crop rotation }\end{array}$ \\
\hline $\begin{array}{l}\text { Fusariosis of the } \\
\text { maize stalk }\end{array}$ & $\begin{array}{l}\text { Causes dark external } \\
\text { lesions or stains at the } \\
\text { lower nodes }\end{array}$ & $\begin{array}{l}\text {-Bury crop residues (cereals, maize). } \\
\text {-Promote crop rotation by avoiding the } \\
\text { continuous cultivation of maize on the same plot }\end{array}$ \\
\hline
\end{tabular}

Source: PIDMA (2014a); PIDMA (2014b); Tchoua (2017).

Malesse (2018); Mozzato et al. (2018); Abdoulaye et al. (2019); Kpadenou et al. (2019). These studies were carried out in the pastoral, agropastoral and forestry sub-sectors but did not consider the farmers' organisation into cooperatives. This study however will complete the previous ones in the literature by focusing on the farmers' organisation (cooperatives) in the food crop sub-sector. Hence, using the case study of the PIDMA project, the objective of this study was to identify the various factors influencing the adoption of agri-environmental practices by maize producers organised in cooperatives and to test the possible relationships existing between the technical and professional support, the socio-economic characteristics and the level of adoption of agri-environmental practices by co-operators.

\section{MATERIALS AND METHODS \\ Study area and data collection}

The field survey was conducted from June to December 2016 in the Centre region of
Cameroon (located at $4.6298^{\circ} \mathrm{N}, 11.7068^{\circ} \mathrm{E}$ ) which was chosen in order to benefit from the closest collaboration with the national coordination of the PIDMA project located in Yaoundé, the county-town of the region and capital-city of Cameroon. Out of the four cooperatives under the PIDMA regional coordinating unit in the Centre region, two were purposively selected for this study: one in Batchenga (AFMABA cooperative) and the other in Mengong (COOPROMAME cooperative). The two cooperatives were selected because of their proximity to the capital-city, Yaoundé, where maize consumption is high and mainly because they recorded the highest maize production among other cooperatives in the region.

All the 15 villages grouping maize producers of the two selected cooperatives were surveyed. Eight of these villages (EmanaBenyada, Nkolmekok, Nalassi, Famenassi, Emana-Batchenga, Long II, Nkoayos and Okongo-Emana) brought together the producers of the AFMABA cooperative 
whereas seven villages (Bilon, Ato'o-Oveng, Mamenye, Essessana, Nnemeyong I, Koungoulou, Nkoleteto) grouped the producers of the COOPROMAME cooperative.

The two selected cooperatives have 135 members in total, including 88 active maize producers distributed as follows: 28 cooperative members registered in AFMABA (including 22 active maize producers) and 107 in COOPROMAME (including 66 active maize producers). The unit of analysis consisted mainly of producers (women and men) of maize PIDMA project beneficiary grouped in the two selected cooperatives. Given the size of the population of 88 active maize producers and the distance between each locality, the survey focused on 50 sampled maize farmers (i.e. $56.8 \%$ of the farmers producing maize), which were proportionally selected on the basis of total number of growers in each village and the distance between one producer and the other.

The data from the maize producers in each locality were collected through the use of questionnaires and interviews, which enabled the researchers to gather information on the socio-economic situation of producers (gender, age, education level, marital status, household size, land area, labour type, source and amount of agricultural income, economic activities, etc); level of knowledge of environmental practices (weeding techniques, adverse effects of activities on the environment, agri-environmental measures put into practice, etc); level of applicability of agrienvironmental measures, perception of environmental degradation, recognition of benefits of proposed agri-environmental practices, cost of implementing the practice, credit alternatives, training provided by the PIDMA project, technical and professional support, etc.

\section{Data analysis}

To achieve the study objective, a logit model was constructed in order to supplement the descriptive statistics arising from the field survey findings.

\section{Justification of the choice of logit model and variables used in the logistic regression}

The utilisation of the logit model arises from the nature of the dependant variable used in order to achieve the study objective. According to Wooldridge (2013), when in a study the dependent variable can take only two modalities (binary or dichotomous variable), the Ordinary Least Squares (OLS) method cannot be used. The Linear Probability Model is therefore not recommended in such a case because of the problems of heterokedasticity, non-normal distribution of the error and the estimation of probabilities outside the range 0 and 1 . To alleviate such problems for this data type, the logit and/or probit models can be used and calculated from the Maximum Likelihood Estimation (MLE) method (Wooldridge, 2013). However, in this study, the logit model was more convenient than the probit model because the sample size is small $(\mathrm{N}=50)$ and the availability of the SPSS computer software (rather than STATA more suitable to compute probit model). According to Wooldridge (2013), a logit model allows the explanatory variables to be either continuous, qualitative or both (continuous and qualitative). The explanatory variables in this study are both continuous and qualitative; therefore, the logit model is more convenient in order to analyse the factors that influence the adoption of agrienvironmental practices.

In scientific circles, the determinants of the adoption of agronomic, economic, environmental or psycho-social orders are the subject of econometric modelling. Thus, several authors have used the logit model in the analysis of the determinants of the adoption of environmental practices. Dupraz (2003) studied agri-environmental practices and the demand for agricultural work in eight EU countries by using the logit model linking the adoption of one or more agri-environmental practices to the demand for agricultural work with equal surface. Similarly, Groulx-Tellier (2012) used this model to characterize factors influencing the adoption of good agrienvironmental practices by crop producers in the Châteauguay River watershed in Québec (Canada). In addition, Etoundi and Kamgnia 
(2014), in the study of the determinants of the adoption of new varieties of maize, like the "Cameroon Maize Series (CMS)" 8704 in the Centre-Cameroon used the logit model probe with instrumentation of belonging to a peasant organisation. More recently, Kpadenou et al. (2019) used the logit model to analyse the socio-economics determinants of the adoption of agro-ecological practices in vegetable production in Niger valley in Benin. Based on these works, the logit model was used in this study for analysing the determinants of the adoption of agri-environmental practices in the maize holdings of the producers benefiting from the PIDMA support.

The logit model used in this study was constructed from several explanatory variables (qualitative and/or quantitative) related to a single qualitative dependant variable (Wooldridge, 2013). The choice of the explanatory variables was made by considering the independent variables used in similar studies from recent literature review. A study by Mabah et al. (2013) on the socioeconomics and institutional determinants of the adoption of the innovative techniques on maize production in West-Cameroon reveals that, the cultivated land area, the marketing orientation of production, the contact with extension agents and the land access mode are the factors determining the probability to have access to the technical package. Nounanwa (2015) analysed the determinants of adoption of integrated fight in horticulture in Québec (Canada). The results indicate that the perceived information and the incitation to adopt an independent adviser are positively correlated to the adoption. Yabi et al. (2016) worked on the identification of factors influencing the adoption of cultural practices of management of soil fertility used in the Ouaké (Benin) municipality. The results revealed that the gender, mode of agricultural practice and land use, adhesion to a cooperative or common initiative group and access to fertilizer positively influences the adoption of mineral fertilizer.

Further studies (e.g. Richer et al., 2005; Mitchell, 2006; Pruneau et al., 2006; Michaud et al., 2009; Mwangi and Kariuki, 2015;
Dhraief et al., 2018; Malesse, 2018; Mozzato et al., 2018; Abdoulaye et al., 2019; Kpadenou et al., 2019) indicated the influence of additional explanatory variables on the adoption of agri-environmental practices in several countries of the world (Ethiopia, Nigeria, Tanzania, Canada, etc). These are the gender, age, education level, marital status, perception of environmental degradation, unrecognition of benefits of proposed practices, cost of implementing the practice, lack of credit possibilities, land area, labour type, time allocated for implementing the practice, farm income, sources of income, agricultural training, technical and professional support. These 15 variables were therefore considered as explanatory variables in the preliminary step of analysis of the logit model used in this study.

The second step of analysis consisted to construct a Pearson correlation matrix which was used to verify the multi-collinearity of the explanatory variables i.e. to check the existence correlation or linear relationship between predictors. This test resulted in the elimination of three "correlated" explanatory variables. These variables are farm income, different sources of income of the producer and lack of knowledge of the benefits of the proposed practices that are correlated respectively with the variables surface area of maize farm, absence or lack of credit possibilities and training. After these preliminary steps, the logit model was run with the remaining 12 uncorrelated explanatory variables.

\section{Mathematical formulation and rationale for variables used in logit model}

The logit model is used to predict the logit of the probability of the occurrence of the event, that is, the natural $\log$ of the odds ratio of having made one or the other decision (adoption or non-adoption of agrienvironmental practices). By denoting $\mathrm{P}$ as the probability of making such decision from the predictors $\mathrm{X}_{1}$ to $\mathrm{X}_{12}$, the mathematical formulation of the logit model used in this study is expressed in Equation (1) such as: 
$Y=\operatorname{Logit}(P)=\operatorname{Ln}\left(\frac{P}{1-P}\right)=\alpha+\beta_{1} X_{1}+$

$\beta_{2} X_{2}+\ldots \ldots \ldots \ldots \ldots \ldots+\beta_{12} X_{12}$

Where: P: is the predicted probability of the occurrence of event (adoption of agrienvironmental practices); 1-P: is the predicted probability of non-occurrence of event (nonadoption of agri-environmental practices); Y: is the dependant variable i.e. group member (adopter or non-adopter of agri-environmental practices) of any selected cooperative producing maize under the PIDMA project; $\mathbf{X}_{\mathbf{1}}$ to $\mathbf{X}_{12}$ : are the explanatory variables according to their described meaning and codification in Table 1.

This study uses the SPSS software program (version 23.0) in order to estimate the descriptive statistics of all variables as well as the logit model coefficients from Equation (1) such as: $\boldsymbol{\beta}_{1}, \boldsymbol{\beta}_{2}, \boldsymbol{\beta}_{3}, \ldots, \boldsymbol{\beta}_{12}$ (termed as $\boldsymbol{\beta}_{\mathbf{k}}$ ) which are respectively the slope coefficients of the explanatory variables $\mathbf{X}_{1}, \mathbf{X}_{2}, \mathbf{X}_{\mathbf{3}}, \ldots, \mathbf{X}_{12}$ (termed as $\mathbf{X}_{\mathbf{k}}$ ); and $\boldsymbol{\alpha}$ : intercept term.

In a binary logit model, the exponentials $\operatorname{Exp}(\mathrm{B})$ of the slope coefficients $\beta_{\mathrm{k}}$ associated to the explanatory variables are interpreted as the Odds Ratio (OR) of the occurrence of the event (adoption of agri-environmental practices) for each increase in the explanatory variable/predictor. A positive $\beta_{\mathrm{k}}$ coefficient generally displays an OR greater than one (OR>1) whereas a negative $\beta_{\mathrm{k}}$ coefficient usually indicates an OR lower than one $(\mathrm{OR}<1)$. Usually, the expression $1 / \operatorname{Exp}(\mathrm{B})$ designates the inverse OR which is computed in order to facilitate the interpretation of the variables with negative coefficients (Wooldridge, 2013).

Table 1: Description of variables used in logistic regression for the study.

\begin{tabular}{lllll}
\hline $\begin{array}{l}\text { Type of } \\
\text { variables }\end{array}$ & $\begin{array}{l}\text { Mathematical } \\
\text { notation }\end{array}$ & Meaning or description & Nature & Code used in SPSS \\
\hline $\begin{array}{l}\text { Dependant } \\
\text { variable }\end{array}$ & $\mathrm{Y}$ & $\begin{array}{l}\text { Group member of any } \\
\text { selected cooperative } \\
\text { producing maize under } \\
\text { the PIDMA project }\end{array}$ & Qualitative & $\begin{array}{l}\text { 1=adopter of agri- } \\
\text { environmental practices; } \\
\end{array}$ \\
& & & $\begin{array}{c}0=\text { non-adopter of agri- } \\
\text { environmental practices. }\end{array}$
\end{tabular}

\begin{tabular}{|c|c|c|c|c|}
\hline \multirow[t]{9}{*}{$\begin{array}{l}\text { Explanatory } \\
\text { variables }\end{array}$} & $\mathrm{X}_{1}$ & Gender of producer & Qualitative & $\begin{array}{l}1=\text { female; } \\
0=\text { male }\end{array}$ \\
\hline & $\mathrm{X}_{2}$ & $\begin{array}{l}\text { Age of producer } \\
\text { (in years) }\end{array}$ & Quantitative & // \\
\hline & $\mathrm{X}_{3}$ & Education level & Qualitative & $\begin{array}{l}1=\text { secondary and more; } \\
0=\text { primary }\end{array}$ \\
\hline & $\mathrm{X}_{4}$ & Marital status & Qualitative & $\begin{array}{l}1=\text { couple; } \\
0=\text { single }\end{array}$ \\
\hline & $\mathrm{X}_{5}$ & $\begin{array}{l}\text { Perception of } \\
\text { degradation of the } \\
\text { environment }\end{array}$ & Qualitative & $\begin{array}{l}1=\text { perceive; } \\
0=\text { does not perceive }\end{array}$ \\
\hline & $\mathrm{X}_{6}$ & $\begin{array}{l}\text { Cost of implementing the } \\
\text { practice }\end{array}$ & Qualitative & $\begin{array}{l}1=\text { not costly at all; } 0=\text { very } \\
\text { costly }\end{array}$ \\
\hline & $\mathrm{X}_{7}$ & $\begin{array}{l}\text { Absence or lack of } \\
\text { financing }\end{array}$ & Qualitative & $\begin{array}{l}1=\text { has finance; } 0=\text { lack of } \\
\text { finance }\end{array}$ \\
\hline & $\mathrm{X}_{8}$ & $\begin{array}{l}\text { Farm size/surface area of } \\
\text { maize farm (in ha) }\end{array}$ & Quantitative & $/ /$ \\
\hline & $\mathrm{X}_{9}$ & Labour type & Qualitative & $\begin{array}{l}1=\text { salary and others; } \\
0=\text { family }\end{array}$ \\
\hline
\end{tabular}




\begin{tabular}{llll}
$\mathrm{X}_{10}$ & $\begin{array}{l}\text { Time spent for the } \\
\text { implementation of the } \\
\text { practice }\end{array}$ & Qualitative & $\begin{array}{l}1=\text { takes less time; } \\
0=\text { takes a lot of time }\end{array}$ \\
\hline $\mathrm{X}_{11}$ & $\begin{array}{l}\text { Training provided by } \\
\text { PIDMA project }\end{array}$ & Qualitative & $\begin{array}{l}1=\mathrm{yes} ; \\
0=\text { no }\end{array}$ \\
\hline $\mathrm{X}_{12}$ & $\begin{array}{l}\text { Technical and } \\
\text { professional support }\end{array}$ & Qualitative & $\begin{array}{l}1=\mathrm{yes} ; \\
0=\text { no }\end{array}$ \\
& & &
\end{tabular}

\section{RESULTS \\ Descriptive field survey findings}

In order to elucidate the descriptive statistics analysis, two assumptions were made: one stating that the level of adoption of agri-environmental practices is dependent on socio-economic constraints and technical and professional support $\left(\mathrm{H}_{\mathrm{a}}\right)$ and the other stipulating that the level of adoption of agrienvironmental practices are independent of socio-economic constraints and technical and professional support $\left(\mathrm{H}_{0}\right)$. The Pearson ChiSquare independence test was used to determine the relationship between socioeconomic characteristics, level of technical support and application of agri-environmental practices (Table 2).

The results of this test show that the determinants of adoption of agrienvironmental practices would be linked to the perception of environmental degradation, lack of knowledge of the benefits of the proposed practices, labour type, agricultural income of the maize farmer and the training received by the maize farmers (Table 2). On the other hand, the relationship between the determinants of adoption of agri-environmental practices and the gender, age, marital status, level of education of producer, the cost of implementing the practice, the lack of funding, the surface area of the maize farm, the time to allocate for the implementation, the producer's sources of income and technical and professional support are not clearly highlighted (Table 2).

Indeed, more than half of the maize producers who do not have a perception of environmental degradation have high level of adoption of agri-environmental practices. This means that producers who perceive at least one problem of erosion in their farm have a low level of adoption of these practices (Table 2). This is due to the fact that the perception of environmental degradation is not only physical as erosion. Hence those who do not have this perception are more attached to new cultural practices.

Also, the more a maize farmer is aware of the benefits of the proposed measures, the higher its level of adoption of agrienvironmental practices. In other words, maize farmers who have knowledge apply agrienvironmental practices more than those who do not (Table 2). This result shows that the training provided by the PIDMA project is a gain for the producers because that is where they learn all these benefits.

In like manner, the more the type of labour is both family and salary, the higher is the level of adoption. Producers with only family or only salary labour are less likely to apply environmental practices (Table 2). This can be explained by the fact that the use of the two types of labour is favourable for the producer because it allows the maize farmer to gain time and also to check compliance with environmental requirements.

Similarly, the more a maize farmer has a better farm income, the higher the level of adoption of agri-environmental practices (Table 2). The observation that is being made here is that maize farmers who have a good performance are more encouraged to apply these practices than those with low returns.

In addition, a maize farmer who has received training from PIDMA project has a high level of adoption of agri-environmental practices as compared to the one who has not received it (Table 2). This is due to the fact that the maize farmers who took part in the trainings acquire new knowledge in good cultural practices. In general, the majority $(82 \%)$ of the maize farmers are well aware of agri-environmental practices prescribed by the PIDMA project because they regularly take part in the training workshops organised by the 
project so this could not be a hindrance to the level of adoption of agri-environmental practices.

Contrary to what would have been expected, no link has been established in this study between the level of adoption of agrienvironmental practices and the producer's gender, age, marital status, education level, the cost of implementing the practices, the absence or lack of funding, the surface area of maize farm, the time to allocate for implementation, the producer income sources, technical and professional support (Table 2).

In summary, it is clear that the level of adoption of agri-environmental practices depends on several social characteristics (perception of environmental degradation, type of labour force) and economic (agricultural income of the producer, ignorance of the benefits of the proposed practices) as well as on expertise and technical support of the personnel of the PIDMA project (training).

\section{Logit model results for the determination of factors influencing the adoption of agri- environmental practices by maize producers}

From Table 3 results, the estimated logit model for this study was validated because in $68 \%$ of cases, the dependent variable is correctly predicted in the model and the Omnibus test of the model coefficients gives a high Pearson Chi-Square value $\left(\chi^{2}=19.644 ; \mathrm{p}\right.$ value $=0.074)$. In addition, most explanatory variables retained with the exception of gender, level of education and time allocated for implementation, have the expected signs (Table 3).

The analysis of factors influencing adoption of agri-environmental practices in the study area is provided by the logit model results of Table 3. The explained results for each explanatory variable are presented separately in this section.

\section{Training provided by PIDMA project}

With regard to training, the positive coefficient of this variable is significant at the $5 \%$ level. This means that maize farmers who have attended training or restitution meetings of trainings are more favourable in adopting environmental practices prescribed by the
PIDMA project than those who have not. In addition, as shown in Table 3, the odds ratio for this variable is 56.296 (greater than 1). This implies that, maize farmers who have benefited from the training have a probability of 56.296 times higher to adopt the practices prescribed by the project.

Farm size (surface area) of maize plantations

As evidenced by its positive and significant coefficient (at 10\% level), the area of maize farm cultivated by the maize producers has an influence on the adoption of environmental practices. For example, maize producers having a considerable maize farm area to cultivate have 2.267 times the opportunity to integrate environmental practices in the field compared to those with a small area (Table 3). This is due to the fact that maize producers with large areas of maize farm have good agricultural incomes, which easily absorb the cost and implementation time of the said practices.

\section{Education}

Although the coefficient of the level of education is not significant, this variable has a positive influence on the adoption of environmental practices in such a way that the educated maize farmers are 1.227 times more likely to adopt technologies that lead to better environmental protection and also to productivity (Table 3 ). Indeed, the fact that the coefficient of this variable is not significant could be due to the high percentage of the educated maize farmers (70\%) in our sample.

\section{Marital status}

Although the coefficient of the variable of marital status is not significant, it has a positive influence on the adoption of environmental practices because maize farmers who are married are 1.488 times more likely to adopt these practices comparatively to those who are single (Table 4). Indeed, the fact that the coefficient of this variable is not significant could also be due to the high percentage of maize farmers who are married $(80 \%)$ in our sample.

\section{Perception of environmental degradation}

The perception of environmental degradation is also a positive factor influencing the adoption of good practices. Although the coefficient of the perception of environmental degradation is not significant, 
this variable also influences positively the adoption of the said practices because the producers who have this perception have a probability of 1.920 times to adopt environmental practices compared to those who do not (Table 3).

\section{Labour type}

Although the coefficient of the type of the labour force is not significant, this variable positively influences the adoption of the said practices because maize farmers who have a family and salary labour are 1.729 times more likely to adopt good agricultural practices than those with only family or salary labour (Table 3). In fact, these producers (with both family and salary labour) will be able to better carry out biological or integrated pest control or apply practices to reduce pesticide use.

\section{Time spent for the implementation of the practice}

Although the coefficient of the variable time to allocate for the implementation of the practice is not significant, this variable also influences positively the adoption of environmental practices because producers who have a family workforce and salary workers have a 1.328 -fold higher probability of adopting environmental practices than those with a family-only workforce (Table 3 ). In fact, these producers complain less about the time it takes to apply good agricultural practices in the field.

\section{Age of maize producers}

Although the coefficient age of the maize farmer is not significant, this variable negatively influences the adoption of environmental practices. Indeed, very old maize producers are 1.011 times less likely to adopt new agricultural technologies compared to those with low ages (relatively young) who are less reluctant to deal with these new technologies (Table 3). In fact, the analysis of this result is parallel to that of gender.

\section{Technical and professional support}

Although this variable is also nonsignificant, it has a positive influence on the adoption of agri-environmental practices because producers receiving technical support from the local agricultural adviser are 5.106 times more likely to adopt these practices compared to those who do not receive them
(Table 3). In fact, the PIDMA project puts at the disposal of the maize producers some local agricultural advisers in order to improve their control of the technical itinerary. Hence this explains the high rate $(84 \%)$ of producers receiving this support.

\section{Gender of maize producers}

Although the producer's gender coefficient is not significant, this variable negatively influences the adoption of environmental practices because the female producers are 3.891 times less likely to adopt these practices than the male producers (Table 3). In fact, women who are few and older feel very tired and are less able to adopt these practices.

\section{Cost of implementing the practice}

At the same time, although the coefficient of the variable cost of implementing the practice is not significant, this variable negatively influences the adoption of environmental practices because a very costly practice has 2.053 times less chance of being adopted by the maize farmers than that which is less costly (Table 3).

\section{Absence or lack of finance}

As for the variable absence or lack of funding, it has a non-significant coefficient and negatively influences the adoption of environmental practices because maize farmers lacking credit facilities have a probability of 4.041 times less to adopt these practices than those with funding (Table 3). Indeed, a maize producer who may not pay the labour force directly to work in his field will be less interested in new agricultural technologies even if they are beneficial to him.

Overall, it was expected that some variables such as: (i) the time to allocate for the implementation of practice, (ii) the gender of the maize producer and (iii) the level of education strongly influence the adoption of the agri-environmental practices. These variables did not have expected signs and in addition are not significant (Table 3). In summary, the adoption of environmental practices by the maize farmers has been associated with an economic characteristic such as the surface area of maize farm and the expertise and technical support such as training. 
Table 2: Relationship between the level of adoption of agri-environmental practices by maize farmers with their socio-economic characteristics and lack of technical or professional support $(\mathrm{N}=50)$.

\begin{tabular}{|c|c|c|c|c|c|c|}
\hline \multirow{2}{*}{\multicolumn{2}{|c|}{ Variables/factors }} & \multicolumn{2}{|c|}{$\begin{array}{c}\text { Level of adoption of } \\
\text { agri-environmental } \\
\text { practices } \\
\end{array}$} & \multicolumn{2}{|c|}{$\begin{array}{l}\chi^{2}-\text { Test } \\
\text { Results }\end{array}$} & \multirow[t]{2}{*}{ Conclusion } \\
\hline & & Low & High & $x^{2}$ & P-value & \\
\hline \multirow[t]{2}{*}{ Gender of producer } & Male & 9 & 21 & 1.701 & 0.427 & Reject $\mathrm{H}_{\mathrm{a}}$ \\
\hline & Female & 8 & 12 & & & \\
\hline \multirow[t]{4}{*}{ Age of producer } & $27-40$ years & 3 & 9 & 4.450 & 0.616 & Reject $\mathrm{H}_{\mathrm{a}}$ \\
\hline & $41-50$ years & 5 & 12 & & & \\
\hline & $51-60$ years & 7 & 7 & & & \\
\hline & $61-70$ years & 3 & 4 & & & \\
\hline \multirow[t]{4}{*}{ Education level } & None & 0 & 0 & 2.013 & 0.733 & Reject $\mathrm{H}_{\mathrm{a}}$ \\
\hline & Primary & 7 & 8 & & & \\
\hline & Secondary & 8 & 17 & & & \\
\hline & University & 3 & 7 & & & \\
\hline \multirow{3}{*}{$\begin{array}{l}\text { Matrimonial } \\
\text { Status }\end{array}$} & Single & 4 & 3 & 2.418 & 0.659 & Reject $\mathrm{H}_{\mathrm{a}}$ \\
\hline & Married & 15 & 25 & & & \\
\hline & Widow & 1 & 3 & & & \\
\hline \multirow[t]{2}{*}{$\begin{array}{l}\text { Perception of } \\
\text { environmental degradation }\end{array}$} & $\begin{array}{l}\text { Does not } \\
\text { perceive }\end{array}$ & 10 & 27 & 16.668 & $0.000 * * *$ & $\begin{array}{l}\text { Accept } \mathrm{H}_{\mathrm{a}} \\
\text { at } 1 \%\end{array}$ \\
\hline & Perceives & 7 & 6 & & & $\begin{array}{l}\text { significance } \\
\text { level }\end{array}$ \\
\hline \multirow{2}{*}{$\begin{array}{l}\text { Unrecognition of benefits } \\
\text { of proposed practices }\end{array}$} & Unrecognises & 6 & 3 & 7.386 & $0.025 * *$ & Accept $\mathrm{H}_{\mathrm{a}}$ \\
\hline & Recognises & 12 & 29 & & & $\begin{array}{l}\text { at } 5 \% \\
\text { significance } \\
\text { level }\end{array}$ \\
\hline \multirow{2}{*}{$\begin{array}{l}\text { Cost of implementing the } \\
\text { practice }\end{array}$} & Very costly & 16 & 27 & 2.493 & 0.287 & Reject $\mathrm{H}_{\mathrm{a}}$ \\
\hline & $\begin{array}{l}\text { Not at all } \\
\text { costly }\end{array}$ & 2 & 5 & & & \\
\hline \multirow{2}{*}{$\begin{array}{l}\text { Absence or lack of credit } \\
\text { possibilities }\end{array}$} & $\begin{array}{l}\text { Lack of } \\
\text { funding }\end{array}$ & 8 & 13 & 1.235 & 0.534 & Reject $\mathrm{H}_{\mathrm{a}}$ \\
\hline & $\begin{array}{l}\text { Does not lack } \\
\text { funding }\end{array}$ & 10 & 19 & & & \\
\hline \multirow{3}{*}{$\begin{array}{l}\text { Surface area of the maize } \\
\text { farm }\end{array}$} & $0.25-1$ ha & 16 & 22 & 4.406 & 0.354 & Reject $\mathrm{H}_{\mathrm{a}}$ \\
\hline & $1.5-2$ ha & 2 & 6 & & & \\
\hline & $2.5-8 \mathrm{ha}$ & 1 & 4 & & & \\
\hline \multirow[t]{3}{*}{ Labour type } & Family & 6 & 6 & 11.764 & $0.019 * *$ & Accept $\mathrm{H}_{\mathrm{a}}$ \\
\hline & Salary & 4 & 4 & & & at $5 \%$ \\
\hline & $\begin{array}{l}\text { Family and } \\
\text { salary }\end{array}$ & 7 & 23 & & & $\begin{array}{l}\text { significance } \\
\text { level }\end{array}$ \\
\hline \multirow{2}{*}{$\begin{array}{l}\text { Time allocated for } \\
\text { implementing } \\
\text { the practice }\end{array}$} & $\begin{array}{l}\text { Takes much } \\
\text { time }\end{array}$ & 9 & 14 & 0.728 & 0.6951 & Reject $\mathrm{H}_{\mathrm{a}}$ \\
\hline & $\begin{array}{l}\text { Takes less } \\
\text { time }\end{array}$ & 10 & 17 & & & \\
\hline
\end{tabular}




\begin{tabular}{|c|c|c|c|c|c|c|}
\hline \multirow[t]{6}{*}{$\begin{array}{l}\text { Agricultural income of } \\
\text { producer }\end{array}$} & $\begin{array}{l}15,000- \\
70,000 \text { FCFA }\end{array}$ & 9 & 15 & \multirow[t]{6}{*}{15.925} & \multirow[t]{6}{*}{$0.014 * *$} & \multirow{6}{*}{$\begin{array}{l}\text { Accept } \mathrm{H}_{\mathrm{a}} \\
\text { at } 5 \% \\
\text { significance } \\
\text { level }\end{array}$} \\
\hline & $\begin{array}{l}80,000- \\
150,000\end{array}$ & 2 & 8 & & & \\
\hline & FCFA & & & & & \\
\hline & $\begin{array}{l}200,000- \\
300,000\end{array}$ & 6 & 3 & & & \\
\hline & FCFA & & & & & \\
\hline & $\begin{array}{l}350,000- \\
1,500,000 \\
\text { FCFA }\end{array}$ & 0 & 7 & & & \\
\hline \multirow{5}{*}{$\begin{array}{l}\text { Sources of income of } \\
\text { producer }\end{array}$} & Farmer & 8 & 14 & \multirow[t]{5}{*}{5.691} & \multirow[t]{5}{*}{0.682} & \multirow[t]{5}{*}{ Reject $\mathrm{H}_{\mathrm{a}}$} \\
\hline & $\begin{array}{l}\text { Farmer and } \\
\text { trader }\end{array}$ & 4 & 9 & & & \\
\hline & $\begin{array}{l}\text { Farmer and } \\
\text { breeder }\end{array}$ & 3 & 2 & & & \\
\hline & $\begin{array}{l}\text { Farmer and } \\
\text { salarial worker }\end{array}$ & 2 & 3 & & & \\
\hline & $\begin{array}{l}\text { Farmer and } \\
\text { retired person }\end{array}$ & 2 & 3 & & & \\
\hline \multirow{2}{*}{$\begin{array}{l}\text { Training provided by } \\
\text { PIDMA project }\end{array}$} & No & 6 & 3 & \multirow[t]{2}{*}{7.386} & \multirow[t]{2}{*}{$0.025 * *$} & Accept $\mathrm{H}_{\mathrm{a}}$ \\
\hline & Yes & 12 & 29 & & & $\begin{array}{l}\text { at } 5 \% \\
\text { significance } \\
\text { level }\end{array}$ \\
\hline \multirow{2}{*}{$\begin{array}{l}\text { Technical and professional } \\
\text { support }\end{array}$} & No & 5 & 3 & \multirow[t]{2}{*}{2.931} & \multirow[t]{2}{*}{0.231} & \\
\hline & Yes & 14 & 28 & & & Reject $\mathrm{H}_{\mathrm{a}}$ \\
\hline
\end{tabular}

Notes: $* * *, * * *:$ Significant at $1 \%, 5 \%, 10 \%$ levels.

Table 3: Logit estimate of determinants of adoption of agri-environmental practices by maize farmers of PIDMA project in the Centre region of Cameroon $(\mathrm{N}=50)$.

\begin{tabular}{|c|c|c|c|c|}
\hline Explanatory variables & $\boldsymbol{\beta}$ & Sig. & $\operatorname{Exp}(\beta)$ & $1 / \operatorname{Exp}(\beta)$ \\
\hline Gender $(0=$ male, $1=$ female $)$ & -1.360 & 0.137 & 0.257 & 3.891 \\
\hline Age (in years) & -0.011 & 0.802 & 0.989 & 1.011 \\
\hline $\begin{array}{l}\text { Level of education } \\
(0=\text { primary, } 1=\text { secondary and more })\end{array}$ & 0.204 & 0.856 & 1.227 & $/ /$ \\
\hline Marital status $(0=$ single, $1=$ couple $)$ & 0.398 & 0.679 & 1.488 & // \\
\hline Perception of degradation of the environment & 0.652 & 0.521 & 1.920 & // \\
\hline \multicolumn{5}{|l|}{$(0=$ does not perceive, $1=$ perceives $)$} \\
\hline $\begin{array}{l}\text { Cost of implementing the practice } \\
(0=\text { very costly, } 1=\text { not costly at all })\end{array}$ & -0.719 & 0.522 & 0.487 & 2.053 \\
\hline
\end{tabular}




\begin{tabular}{|c|c|c|c|c|}
\hline $\begin{array}{l}\text { Absence or lack of finance } \\
(0=\text { lack of finance, } 1=\text { has finance })\end{array}$ & -1.405 & 0.114 & 0.245 & 4.041 \\
\hline Farm size (surface area) of maize plantations (in ha) & 0.819 & $0.099^{*}$ & 2.267 & // \\
\hline $\begin{array}{l}\text { Type of labour } \\
\text { ( } 0=\text { family, } 1=\text { salary and others) }\end{array}$ & 0.548 & 0.680 & 1.729 & $/ 1$ \\
\hline Time spent for implementation of the practice & 0.284 & 0.813 & 1.328 & $/ /$ \\
\hline$(0=$ takes a lot of time, $1=$ takes less time $)$ & & & & \\
\hline Training provided by PIDMA project $(0=$ no, $1=y e s)$ & 4.031 & $0.019 * *$ & 56.296 & // \\
\hline $\begin{array}{l}\text { Technical and professional support } \\
(0=\text { no, } 1=\text { yes })\end{array}$ & 1.630 & 0.147 & 5.106 & $/ /$ \\
\hline Constant & -5.298 & & $/ /$ & $/ 1$ \\
\hline TOTAL & \multicolumn{4}{|c|}{$\begin{array}{l}-2 \text { Log likelihood }=49.350 \\
\text { Nagelkerke } R^{2}=0.434 \\
\text { Percentage correct prediction= }=68 \% \\
\text { Omnibus test } \chi^{2}=19.664 \\
\text { Hosmer \& Lemeshow test } \chi^{2}=19.664\end{array}$} \\
\hline
\end{tabular}

Notes: ${ }^{* * *},{ }^{* *}, *$ : Significant at $1 \%, 5 \%, 10 \%$ levels

\section{DISCUSSION}

\section{Adoption of environmental practices according to the selected factors}

The factors influencing the adoption of environmental practices in the study area are already presented in the previous sections of this paper. The discussion of the significance, socio-economic and environmental relevance of computed results compared to other studies are presented in this part.

\section{Training provided by PIDMA project}

This factor significantly and positively influences the adoption of agri-environmental practices. In Table 3, maize producers who have benefited from the training have a probability of 56.296 times higher to adopt the practices prescribed by the PIDMA project. When compared to those who have not benefited, this is explained by the fact that the maize producers benefiting from the training acquire new knowledge in terms of good agricultural practices conducive to the environment and beneficial to human health. This will help them to limit bad practices and thus better align with environmental or agrienvironmental requirements. This result is consistent with a previous research, which has shown that the presence of technical support (training) to implement some more demanding measures is certainly a factor that positively promotes the adoption of good practices (Groulx-Tellier, 2012). It has also been found on the field that the trained maize producers have abandoned bad practices and are gradually adapting to the good practices that have been taught during the training and, above all, continue to raise awareness among the members of the untrained maize producers. Farm size (surface area) of maize plantations

In Table 3, the size of maize farm is also a factor that positively and significantly influences the adoption of these environmental practices prescribed by the PIDMA project. This is due to the fact that maize producers with large area of maize farm have good agricultural incomes, which easily absorb the cost and implementation time of the said practices. This result is in line with Richer et 
al. (2005), which has shown that producers with large production basins better adopt agrienvironmental practices because the cost and time of implementation of these practices are easily absorbed by their farm income. During field visit, the observation made is that the maize producers, especially those of AFMABA (Batchenga) still have large plantation areas and invest for the success of their farm in order to obtain a good yield. Hence the cost of production can be easily absorbed by the total costs. This finding corroborates those of Mwangi and Kariuki (2015); Malesse (2018); Mozzato et al. (2018) which cast more light on the importance of large farm size i.e. positive effect of large farm size on adoption of environmentally friendly family practices. The analyses further argue that the positive effect of farm size on adoption is often linked to higher flexibility in terms of decision-making, greater access to resources and more opportunities to test new practices on small sample plots. Nevertheless, it is worth nothing that in the same literature, the impact of farm size on adoption and intensity of use agricultural technologies on the other hand, is not consistently similar in various adoption studies (Malesse, 2018).

\section{Education}

With regard to the level of education, this factor positively influences adoption despite the fact that its coefficient is not significant. This finding corroborates that of Mwangi and Kariuki (2015) and Dhraief et al. (2018) who stated that educated producers have a better chance of adopting technologies that lead to better productivity and therefore better protection of the environment.

\section{Marital status}

The marital status factor also has a positive influence on the adoption of environmental practices. This result goes in line with the study by Chatterjee et al. (2012) and Nagata et al. (2012) demonstrating that married producers are more likely to adopt these practices because they receive support (intellectual, physical, financial, etc.) from their partner.

\section{Perception of environmental degradation}

The adopter perception paradigm argues that the adoption process starts with the perception that there is a need to innovate. This perception is determined by personal factors (e.g. human values, education and experience) as well as physical factors of the land and institutional factors, e.g. raising awareness through extension (Prager and Posthumus, 2010). In this study, the perception of environmental degradation is a positive factor influencing the adoption of good practices. This result corroborates that by Richer et al. (2005), which demonstrated that the perception of environmental issues is considered an essential condition for the adoption of good practices. However, it is very difficult to perceive environmental degradation especially when it comes to the impact of pesticides in water or on the ground.

\section{Labour type}

It has been found in the field that maize producers with only a family labour force complain a lot about the drudgery of the work in view of the size of the farm. Similarly, those who have a salaried workforce are still unable to control the work of the workers especially with regard to environmental requirements. This is why maize farmers who have both family and salary workforce adopt these prescriptions more because they have sufficient manpower and above all have the opportunity to control the work of the workers. This explains the fact that the standard factor of the workforce positively influences the adoption of environmental practices.

\section{Technical and professional support}

Field studies have shown that more than the majority of producers received support in the form of proximity to agricultural advisory services (Conseiller Agricole de Proximité$C A P)$ except for maize producers who have their farms either very far away or difficult to reach. Hence, the technical and professional support factor positively influences the adoption of environmental practices. This result is in line with that of Groulx-Tellier (2012) which demonstrated that the presence of technical support, such as mentoring and follow-up, to put in place some more demanding measures is certainly a factor that positively favours the adoption of these practices. 


\section{Time spent for the implementation of the practice}

The time allocated for the implementation of practice is a factor that also influences positive adoption because producers working with both types of labour complain less about this time. This result is contrary to those of Groulx-Tellier (2012) and Richer et al. (2005) who demonstrated that an agri-environmental practice that requires enough time would be less adopted by producers especially those with small production pools.

\section{Age of maize producers}

The age of the maize producers is a factor that influences adoption negatively. This is the same as that of Richer et al. (2005) whose results from some studies showed that more experienced and older agricultural producers were generally more reluctant to adopt conservation methods since they tended to minimise the impact of environmental problems and this was actually verified in the field. This is corroborated by findings of Mwangi and Kariuki (2015) in their study of factors determining adoption of agricultural practices in developing countries.

\section{Cost of implementing the practice}

The cost factor of implementing the practice negatively influences adoption. The field observation was in perfect similarity to that of the Centre for Reference of Agriculture and Agri-Food of Quebec-CRAAQ (2007), which showed that if the adoption of good agrienvironmental practice results in increased costs of production and/or an important basic investment, farmers would generally not adhere to it.

\section{Absence or lack of finance}

Maize producers lacking credit possibilities are certainly willing to adopt environmental requirements but complain about their cost. Many producers are at that level, which is a negative influence on adoption. This result is in line with the Centre for Reference of Agriculture and Agri-Food of Quebec-CRAAQ (2007) because a producer who complains about the cost of implementation and lacks credit possibilities will not necessarily adhere to it.

\section{Gender of maize producers}

Although women representation in the sample is significant, there has been an ageing of the latter. Thus, the producer's gender factor negatively influences the adoption of environmental practices because, by browsing the literature, it was mentioned that women were more sensitive to environmental concerns than men (Richer et al., 2005). This result is contrary to that of Richer et al. (2005) because in our study, it is men who are more sensitive.

From the forgone analysis and discussions of results, it is possible to draw up the main factors influencing either positively and significantly, positively and insignificantly, or negatively and insignificantly the adoption of practices by the maize producers. In increasing order of importance: (i) economic, (ii) expertise and technical support and (iii) social and psychological. The collection of data from the maize farmers of AFMABA and COOPROMAME has also revealed the great influence of economic factors however; secondly it is rather the social and psychological factors. These results elicit the following questioning: How can the strategy of agricultural producers be improved in order to encourage the adoption of agri-environmental practices? This question was posed to the cooperators during the investigation and the discussions generated the recommendations/incentives in the section below.

\section{Incentives to improve the adoption of environmental practices}

These could be undertaken through the financial assistance and field demonstration among producers.

\section{Improvements in financial incentives}

Financial assistance should be made easily accessible to the farmers to assist adoption of agri-environmental practices. According to this study, the main factor limiting the adoption of agri-environmental practices is economic (lack of possibilities for credit). For example, certain practices mainly aimed at Integrated Pest Management (e.g. respecting the formulas of balanced fertility; 
harvesting and incineration of diseased plants; practice of crop rotation; elimination of too many plants) are not attractive to agricultural producers. Apart from their time-consuming constraints, these measures need an important initial investment, which does not even guarantee their profitability after their implementation. A more adequate and accessible financial support targeting the least profitable practices could be put forward by the PIDMA to enhance adoption of agrienvironmental measures.

\section{Field demonstrations among producers}

The purpose of these demonstrations would be to present concretely the adoption process of an agri-environmental method and to allow the exchange of knowledge between producers of the same sector. According to few respondents, agricultural producers have a great influence on each other. They are therefore in the best position to talk to each other about their experiences in agriculture. To ensure adoption of agri-environmental practices, the PIDMA project should assign an environmental assistant to each cooperative. The agri-environmental efforts of agricultural producers should also be made much more available publicly to create awareness in the environment. This type of strategy would positively influence the perceptions of the general public in relation to the activities of agricultural producers. In short, the adoption of environmentally beneficial behaviour is a complex process and largely depends on the environment in which the agricultural producer evolves (CRAAQ, 2007). Given the peculiarities of each agricultural producer, it seems that a specific approach during the mentoring and follow-up is more beneficial (CRAAQ, 2007).

\section{Conclusion and policy implications Conclusion}

This study sought to analyse the main factors limiting or promoting the adoption of agri-environmental practices by the maize producers in the cooperatives of the AFMABA and COOPROMAME of the respective localities of Batchenga and Mengong in the Centre region of Cameroon. The findings of the study contended that majority of the maize farmers are well aware of agri-environmental practices prescribed by the PIDMA project because they regularly take part in the training workshops organised by the project; so this could not be a hindrance to the level of adoption of agri-environmental practices. The Chi-Square test revealed that the level of adoption of agri-environmental practices was related to social and psychological characteristics (perception of environmental degradation, labour force type) and economic (producer's farm income, lack of knowledge of benefits of the proposed practices), expertise and technical support (training provided by PIDMA project). The results of logistic regression model reveal that the adoption of agri-environmental practices was associated with training and the surface area of maize farm. However, certain determinants (including gender, age, level of education, marital status, perception of environmental degradation, cost of implementing practice, lack of funding, type of manpower, time to allocate for implementation of the practice and technical support) did not seem to be associated with the adoption of agrienvironmental practices in our sample. From the forgone analysis and discussion of results, it is possible to draw up the main factors influencing either positively and significantly, positively and insignificantly, or negatively and insignificantly the adoption of practices or measures by the maize farmers. In increasing order of importance, these factors are: (i) economic, (ii) expertise and technical support and (iii) social and psychological. The analysis of data from the maize farmers of AFMABA and COOPROMAME also revealed the great influence of economic factors however; secondly it is rather the social and psychological factors. The Chi-Square test and logistic regression model results are complementary and reinforce the findings of this study.

\section{Policy implications}

In order to improve the adoption of environmental practices, the government should formulate specific policies targeting maize producing farmers and to the 
agricultural development projects. To the maize farmers, this study recommends the setting up of working groups of at least 10 maize producers in order to practice rotations in the fields of each member of the group. This union will help promote demonstrations of agri-environmental practices with the assistance of the "Local Agricultural Technical Advisers" and to raise awareness in terms of good agri-environmental practices proposed by the agricultural development projects.

The study also recommends the agricultural development projects to define and provide relatively simple mechanisms to enhance performance such as financial assistance, demonstration workshops in fields of good agri-environmental practices and to allocate environmental assistants to each cooperative's headquarters. Also, the agricultural development projects should continue to seek new agri-businesses for the signing of contracts with cooperatives in order to ensure better incomes for maize producers through the stabilization of the prices of the $\mathrm{kg}$ of maize. This will encourage them to continue the activity and to enhance respect of the environmental requirements especially if the agri-business is very demanding, especially with purchase of the product. In the event of dominant maize diseases, maize producers are encouraged to adopt practices prescribed by the agricultural development projects including biological control against pests and insecticides' use. In short, knowledge of the factors limiting the adoption of some good agri-environmental practices by the agricultural development projects is an essential tool to improve the programme and policies currently in place.

\section{COMPETING INTERESTS}

The authors declare that they have no competing interests.

\section{AUTHORS' CONTRIBUTIONS}

TLV interviewed the participants and conceived the research protocol. AJJF conceived the study design, did the statistical analysis and data modelling and reviewing of the manuscript. GAM initiated the write up of the manuscript and participated in the English proof reading of the article.

\section{ACKNOWLEDGEMENTS}

The authors are grateful to the PIDMA project for granting an internship to the second author which enabled data collection for the study. We also thank the three anonymous reviewers for their constructive criticism, which helped to significantly improve our paper.

\section{REFERENCES}

Abdoulaye IM, Ayena M, Yabi AJ, Dedehouanou H, Biaou G, Houinato M. 2019. Incidences socio-économiques et environnementales des infrastructures pastorales et agro-pastorales installées dans le Borgou au Nord-Est du Bénin. International Journal of Biological and Chemical Sciences, 13(7): 3214-3233. DOI: https://dx.doi.org/10.4314/ijbcs.v13i7.20

Binswanger HP, Sillers DA. 2003. Risk aversion and credit constraints in farmers' decision-making: a reinterpretation. The Journal of Development Studies, 20(1): 5-21.

Bokobana A, Toundou O, Odah K, Dossou KSS, Tozo K. 2019. Enhancement of proline content and antioxidant enzyme activities induced by drought stress in maize (Zea Mays L.) by application of compost. International Journal of Biological and Chemical Sciences, 13(7): 2978-2990. DOI: https://dx.doi.org/10.4314/ijbcs.v13i7.1

CRAAQ (Centre for Reference of Agriculture and Agri-Food of Quebec). 2007. Mandat de recherche: les bonnes pratiques agro-environnementales, fiche de travail: les bonnes pratiques agroenvironnementales. CRAAQ. From http://www.craaq.gouv.qc.ca/ (Retrieved February 18, 2019).

Chatterjee N, Fernandes G, Hernandez M. 2012. Food insecurity in urban poor households in Mumbai, India. Food Security, 4(4): 619-632. DOI: 10.1007/s12571-012-0206-Z 
Dhraief MZ, Bedhiaf-Romdhani S, Dhehibi B, Oueslati-Zlaoui M, Jebali O, BenYoussef S. 2018. Factors affecting the adoption of innovative technologies by livestock farmers in arid area of Tunisia. FARA Research Report, 3(5):1-22.

Dupraz P. 2003. Mesures agroenvironnementales et demande de travail agricole. Working Paper, Institut National de Recherche Agronomique, Rennes, France, 26 p.

Etoundi SM, Kamgnia DB. 2014. Determinants of the adoption of improved varieties of maize in Cameroon: case of CMS 8704. Proceedings of the African Economic Conference, $23^{\text {rd }}-26^{\text {th }}$ May 2014, Nairobi, Kenya.

Groulx-Tellier E. 2012. Facteurs influençant l'adoption de bonnes pratiques Agroenvironnementales par les producteurs de grandes cultures dans le bassin versant de la rivière Châteauguay. Mémoire de fin d'études présenté en vue de l'obtention du grade de Maître en Environnement (M. Env.), Centre Universitaire de Formation en Environnement Sherbrooke, Québec, Canada, p.13-23.

Jaza FAJ. 2017. Comparing the benefits between producing maize for seeds or consumption in Cameroon. Tropicultura, 35(2): 87-101. DOI : http://www.tropicultura.org/text/v35n2/ 87.pdf

Kpadenou CC, Tama C, Tossou BD, Yabi JA. 2019. Déterminants socio-économiques de l'adoption des pratiques agroécologiques en production maraîchère dans la vallée du Niger au Bénin. International Journal of Biological and Chemical Sciences, 13(7): 3103-3118. DOI:

https://dx.doi.org/10.4314/ijbcs.v13i7.11

Prager K, Posthumus H. 2010. Socioeconomic factors influencing farmers' adoption of soil conservation practices in Europe. Human Dimensions of Soil and Water Conservation. Nova Science Publishers, New York, USA.
Malesse B. 2018. A review on factors affecting adoption of agricultural new technologies in Ethiopia. The Journal of Agricultural Science and Food Research, 9 (3): 1-4.

Marinis PD, Spada A, Aristil J. 2019. Evaluation des paramètres productifs et quantification d'aflatoxine de sept variétés de maïs (Zea mays L.) testées en Haïti. International Journal of Biological and Chemical Sciences, 13(7): 3009-3022. DOI: https://dx.doi.org/10.4314/ijbcs.v13i7.3

Michaud A, Ruyet F, Beaudin I. 2009. Évaluation des outils de gestion agroenvironnementale à l'échelle du bassin versant dans un cadre opérationnel de service-conseil à la ferme et dans le cadre du projet lisière verte. Québec, Institut de recherche et de développement en agroenvironnement (IRDA), Coopérative de solidarité du bassin versant de la rivière au Brochet, Dura-Club, AAC (PASCAA) et MAPAQ, 63 p.

Minader (Ministère de l'Agriculture et du Développement Rural). 2018. Annuaire des statistiques du secteur agricole, campagne 2017/2018. Division des Etudes et Projets Agricoles, Cellule des Enquêtes et Statistiques, Yaoundé, Cameroun. http://www.minader.gv.cm (Retrieved January 14, 2019).

Minef (Ministère de l'Environnement et des Forêts). 2016. Plan national de gestion de l'environnement, Volume II, Analyse des secteurs d'intervention. MINEF, Yaoundé, Cameroun, 582 pp.

Mitchell R. 2006. Study on identifying rural sociological barriers to adoption. Research report, Alberta Research Council, Alberta, Canada, 224 p.

Mozzato D, Gatto P, Defrancesco E, Bortolini L, Pirotti F, Pisani E, Sartori L. 2018. The role of factors affecting the adoption of environmentally friendly farming practices: can geographical context and time explain the differences emerging from literature? The Journal of Sustainability, 10(9): 1-23. DOI: 
$10.3390 /$ su10093101

Mwangi M, Kariuki S. 2015. Factors determining adoption of new agricultural technology by smallholder farmers in developing countries. Journal of Economics and Sustainable Development, 6(5): 15-20.

Nonga NF. 2002. Gestion soutenable de la forêt et développement intégré au Cameroun. Thèse de Doctorat d'Etat, Université de Yaoundé II-Soa, Yaoundé, Cameroun, $385 \mathrm{p}$.

PIDMA. 2014a. Résumé du cadre de gestion environnementale et sociale. Coordination Nationale du Projet PIDMA, Yaoundé, Cameroun.

PIDMA. 2014b. Manuel d'exécution du projet. Coordination Nationale du Projet PIDMA, Yaoundé, Cameroun.

Pruneau D, Doyon A, Langis J, Vasseur L, Martin G, Ouellet E, Boudreau G. 2006. L'adoption de comportements environnementaux: motivations, barrières et facteurs facilitants. UQAM.

Richer N, Needeman R. 2005. Études des perceptions des agriculteurs du bassin versant de la rivière aux Raisins concernant l'impact de l'agriculture sur la qualité de l'environnement de la région. Ottawa, Institut de Recherche sur l'Environnement et l'Economie,
Université d'Ottawa, Canada, 195 pp.

Tchoua LV. 2017. Facteurs influençant l'adoption des mesures agroenvironnementales dans les exploitations de maïs des coopératives bénéficiaires du PIDMA: cas des coopératives AFMABA et COOPROMAME des localités respectives de Batchenga et Mengong. Mémoire de Fin d'Etudes en vue de l'obtention du Master en Economie et Management de l'Environnement, CRESA Forêt-Bois de NkolbissonYaoundé, Université de Dschang, Cameroun, $97 \mathrm{p}$.

Vojtech V. 2010. Les Mesures Prises face aux Problèmes Agro-environnementaux. Éditions OCDE. DOI: 10.1787/5kmjrzdr9s6c-fr, $6 \mathrm{p}$.

Yabi JA, Bachabi FX, Labiyi AI, Ayena RL. 2016. Déterminants socio-économiques de l'adoption des pratiques culturales de gestion de la fertilité des sols utilisés dans la commune de Ouaké au NordOuest du Benin. International Journal of Biological and Chemical Sciences, 10(2): 779-792. DOI: 10.4314/ijbcs.v10i2.27

Wooldridge JM. 2013. Introductory econometrics: a modern approach. South-Western College Publishing: Mason/Ohio, USA. 